\title{
Phase equilibria in the system $\mathrm{Ce}-\mathrm{Ni}-\mathrm{C}$ at $800^{\circ} \mathrm{C}$ in the range 0-33.3 at.\% Ce and new isostructural compounds $R_{2} \mathrm{Ni}_{5} \mathrm{C}_{3}$ $(R=\operatorname{Pr}, \mathrm{Nd})$
}

\author{
Mykola HEMBARA $^{1 *}$, Volodymyr LEVYTSKYY ${ }^{1}$, Volodymyr BABIZHETSKYY ${ }^{1}$, Bogdan KOTUR $^{1}$ \\ ${ }^{1}$ Department of Inorganic Chemistry, Ivan Franko National University of Lviv, \\ Kyryla i Mefodiya St. 6, 79005 Lviv, Ukraine \\ * Corresponding author.Tel.: +380-96-4179192; e-mail: hembaramukola@gmail.com
}

Received May 25, 2016; accepted June 29, 2016; available on-line November 7, 2016

The phase equilibria in the ternary system $\mathrm{Ce}-\mathrm{Ni}-\mathrm{C}$ at $800^{\circ} \mathrm{C}$ in the range $0-33.3$ at. $\%$ Ce were investigated by means of $\mathrm{X}$-ray diffraction and energy-dispersive spectroscopy. Three ternary, $\mathrm{CeNiC}_{2}, \mathrm{Ce}_{2} \mathrm{Ni}_{5} \mathrm{C}_{3}, \mathrm{and}$ $\mathrm{Ce}_{2} \mathrm{Ni}_{22} \mathrm{C}_{2.75}$, and five binary $\mathrm{Ce}-\mathrm{Ni}$ and $\mathrm{Ce}-\mathrm{C}$ compounds at $800^{\circ} \mathrm{C}$ were confirmed. Two new isostructural ternary compounds (structure type $\mathrm{La}_{2} \mathrm{Ni}_{5} \mathrm{C}_{3}$, space group $\left.P 4 / \mathrm{mbm}\right): \operatorname{Pr}_{2} \mathrm{Ni}_{5} \mathrm{C}_{3} \quad(a=8.2888(1) \AA$, $c=3.95343(8) \AA)$ and $\mathrm{Nd}_{2} \mathrm{Ni}_{5} \mathrm{C}_{3} \quad(a=8.2810(2) \AA$, $c=3.9292(1) \AA$ ), were synthesized and their crystal structures were refined. The compounds continue the isostructural series of $R_{2} \mathrm{Ni}_{5} \mathrm{C}_{3}$ ternary carbides with $\mathrm{La}_{2} \mathrm{Ni}_{5} \mathrm{C}_{3}$-type structure.

Carbides / Phase equilibria / Crystal structure / Isostructural compounds

\section{Introduction}

The binary systems of carbon with rare-earth and transition elements have been widely investigated. However, ternary $R-T-\mathrm{C}$ systems $(R=$ rare-earth element, $T=$ transition element) have not yet been systematically investigated, although several ternary compounds of these systems, especially with light rare-earths, display interesting crystal structures, chemical bonding and physical properties.

The ternary systems (Y, La, Ce)-Ni-C have been investigated at $400^{\circ} \mathrm{C}$ in the full concentration range, and selected alloys examined at higher temperatures [1]. The ternary systems $\mathrm{Gd}-\mathrm{Ni}-\mathrm{C}$ and $\mathrm{Y}-\mathrm{Ni}-\mathrm{C}$ have also been investigated, the former at $600^{\circ} \mathrm{C}$ and the latter at $800^{\circ} \mathrm{C}[2,3]$. Four ternary compounds have been reported to occur in the system $\mathrm{Ce}-\mathrm{Ni}-\mathrm{C}$ at $400^{\circ} \mathrm{C}: \mathrm{CeNiC}_{2}$ [1,4,5], $\sim \mathrm{CeNi}_{3} \mathrm{C}_{2}$ [1], $\mathrm{CeNi}_{5} \mathrm{C}_{4}$ [1], and $\mathrm{Ce}_{2} \mathrm{Ni}_{22} \mathrm{C}_{3}$ [1,6]. Later, the compositions of the two ternary carbides $\sim \mathrm{CeNi}_{3} \mathrm{C}_{2}$ and $\mathrm{Ce}_{2} \mathrm{Ni}_{22} \mathrm{C}_{3}$ were refined to $\mathrm{Ce}_{2} \mathrm{Ni}_{5} \mathrm{C}_{3}$ [7,8] and $\mathrm{Ce}_{2} \mathrm{Ni}_{22} \mathrm{C}_{2.75}$ [9]. In addition, the ternary compounds $\mathrm{CeNi}_{8} \mathrm{C}_{2}$ and $\mathrm{Ce}_{2} \mathrm{Ni}_{5} \mathrm{C}_{2}$ were synthesised at high pressures and temperatures $[10,11]$. Isostructural compounds $R \mathrm{NiC}_{2}$ and $R_{2} \mathrm{Ni}_{22} \mathrm{C}_{2.75}$ (structure type $\mathrm{CeNiC}_{2}$ and $\mathrm{Ce}_{2} \mathrm{Ni}_{22} \mathrm{C}_{2.75}$, respectively) are known for almost all rare-earths. But ternary carbides $R_{2} \mathrm{Ni}_{5} \mathrm{C}_{3}$ (structure type $\mathrm{La}_{2} \mathrm{Ni}_{5} \mathrm{C}_{3}[1,12]$ ) have been synthesized and investigated only for $R=\mathrm{La}$ and $\mathrm{Ce}$.
In this work we report on the phase equilibria in the ternary system $\mathrm{Ce}-\mathrm{Ni}-\mathrm{C}$ at $800^{\circ} \mathrm{C}$ in the range 0-33.3 at.\% $\mathrm{Ce}$ and on the new isostructural compounds $R_{2} \mathrm{Ni}_{5} \mathrm{C}_{3}(R=\mathrm{Pr}, \mathrm{Nd})$ with $\mathrm{La}_{2} \mathrm{Ni}_{5} \mathrm{C}_{3}$-type structures.

\section{Experimental}

0.5 and 1.0 g-alloys of different compositions of cerium, praseodymium, neodymium, nickel, and carbon, were prepared by arc-melting cold-pressed pellets of powders of the initial elements with purities not less than 99.9 wt.\% (Alfa Aesar / Johnson Matthey) under argon atmosphere purified with $\mathrm{Ti}$ getter, on a water-cooled copper hearth, using a nonconsumable tungsten electrode. During the melting procedure the weight losses were $<1.0 \mathrm{wt} . \%$ of the total mass of the ingots. The alloys were annealed in evacuated quartz ampoules at $800^{\circ} \mathrm{C}$ for 25 days.

Phase analysis of the alloys and crystal structure refinements (using $\mathrm{Si}$ as internal standard for refinement of the cell parameters, $a=5.43075 \AA$ ) were performed with the help of the WinXPOW [13] and WinCSD program packages [14], using powder X-ray diffraction (XRD) data obtained with DRON-3.0M $(\mathrm{Cu} K \alpha)$ and Stoe Stadi P $\left(\mathrm{Cu} \mathrm{K \alpha _{1 } )}\right.$ powder diffractometers. Metallographic, qualitative and quantitative composition analyses of polished 
samples were performed by energy-dispersive X-ray spectroscopy (EDX) with a scanning electron microscope REMMA-102-02. For metallographic and EDX analysis the alloys were embedded in Wood's metal (melting point $70^{\circ} \mathrm{C}$ ). The embedded samples were polished on a wool cloth using abrasive materials with various grain sizes $(0.5-5 \mu \mathrm{m})$ in dried paraffin oil. Surface cleaning and protecting of the polished samples were performed using petroleum ether.

\section{Results and discussion}

The isothermal section of the $\mathrm{Ce}-\mathrm{Ni}-\mathrm{C}$ phase diagram at $800^{\circ} \mathrm{C}$ in the range $0-33.3$ at. $\%$ Ce determined in this work, and the previously reported section at $400^{\circ} \mathrm{C}$ [1], are shown in Fig. $1 a$ and $b$, respectively. The alloys used for the investigation and their phase composition according to the XRD and EDX analyzes are indicated in Fig. 1a. The existence of five binary compounds was confirmed: $\mathrm{CeNi}_{5}, \mathrm{Ce}_{2} \mathrm{Ni}_{7}, \mathrm{CeNi}_{3}$, $\mathrm{CeNi}_{2}$ and $\alpha-\mathrm{CeC}_{2}$. The refined cell parameters are listed in Table 1. The lattice parameters of the binary $\mathrm{Ce}-\mathrm{Ni}$ phases and $\alpha-\mathrm{CeC}_{2}$ in alloys of the binary and ternary systems are practically the same, i.e. the binary $\mathrm{Ce}-\mathrm{Ni}$ compounds and $\alpha-\mathrm{CeC}_{2}$ do not dissolve carbon and nickel, respectively, at $800^{\circ} \mathrm{C}$. Three ternary compounds exist in the system at $800^{\circ} \mathrm{C}: \mathrm{Ce}_{2} \mathrm{Ni}_{22} \mathrm{C}_{2.75}$, $\mathrm{Ce}_{2} \mathrm{Ni}_{5} \mathrm{C}_{3}$, and $\mathrm{CeNiC}_{2}$. Their crystal structure data are summarized in Table 2. The ternary carbide $\mathrm{CeNi}_{5} \mathrm{C}_{4}$, which was reported to occur at $400^{\circ} \mathrm{C}$ [1], was not observed at $800^{\circ} \mathrm{C}$. The following three-phase regions: $<\mathrm{CeNiC}_{2}+\mathrm{Ce}_{2} \mathrm{Ni}_{5} \mathrm{C}_{3}+\mathrm{CeNi}_{5} \mathrm{C}_{4}>,<\mathrm{CeNi}_{5}+\mathrm{Ce}_{2} \mathrm{Ni}_{5} \mathrm{C}_{3}$ $\left.+\mathrm{CeNi}_{5} \mathrm{C}_{4}\right\rangle,\left\langle\mathrm{CeNi}_{5}+\mathrm{Ce}_{2} \mathrm{Ni}_{22} \mathrm{C}_{2.75}+\mathrm{CeNi}_{5} \mathrm{C}_{4}>\right.$ and $<\mathrm{C}+\mathrm{Ce}_{2} \mathrm{Ni}_{22} \mathrm{C}_{2.75}+\mathrm{CeNi}_{5} \mathrm{C}_{4}>$, which were reported to occur at $400^{\circ} \mathrm{C}$ [1], were not confirmed at $800^{\circ} \mathrm{C}$.
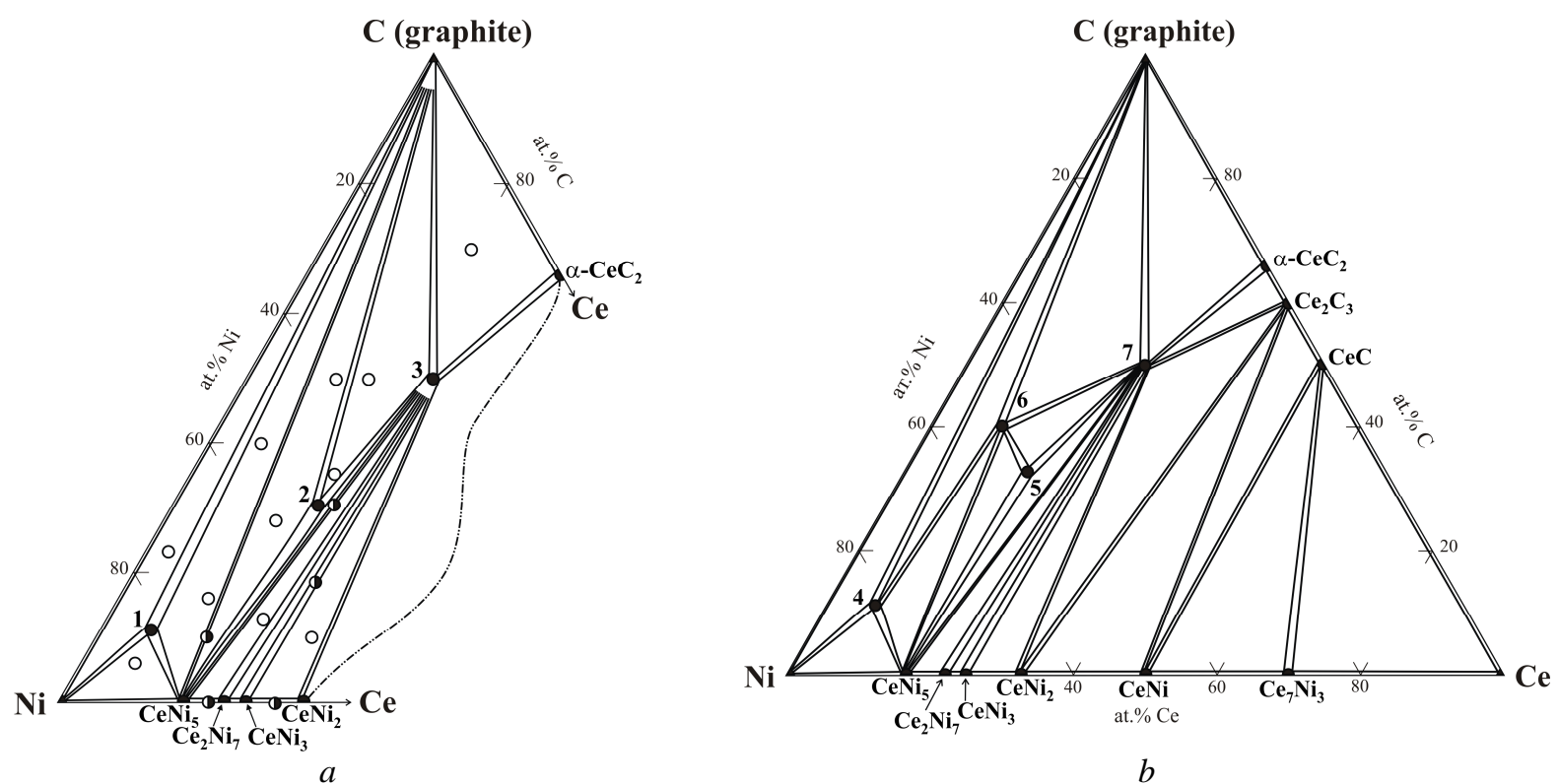

Fig. 1 Isothermal section of the $\mathrm{Ce}-\mathrm{Ni}-\mathrm{C}$ phase diagram at $800^{\circ} \mathrm{C}$ in the range $0-33.3$ at.\% $\mathrm{Ce}(a)$ and at $400^{\circ} \mathrm{C}[1](b)$. The compositions of the alloys used in the investigation are indicated in $(a)(\bigcirc-$ three-phase alloy, - two-phase alloys, - - single-phase alloys). Ternary compounds: $\mathbf{1}, \mathbf{4}-\mathrm{Ce}_{2} \mathrm{Ni}_{22} \mathrm{C}_{2.75} ; \mathbf{2}-\mathrm{Ce}_{2} \mathrm{Ni}_{5} \mathrm{C}_{3}$; $\mathbf{3}, \mathbf{7}-\mathrm{CeNiC}_{2} ; \mathbf{5}-\sim \mathrm{CeNi}_{3} \mathrm{C}_{2} ; \mathbf{6}-\mathrm{CeNi}_{5} \mathrm{C}_{4}$.

Table 1 Crystallographic data of $\alpha-\mathrm{CeC}_{2}$ and binary $\mathrm{Ce}-\mathrm{Ni}$ phases in the $\mathrm{Ce}-\mathrm{Ni}-\mathrm{C}$ system at $800^{\circ} \mathrm{C}$.

\begin{tabular}{|c|c|c|c|c|c|c|c|}
\hline Compound & $\begin{array}{c}\text { Structure } \\
\text { type }\end{array}$ & $\begin{array}{l}\text { Pearson } \\
\text { symbol }\end{array}$ & $\begin{array}{l}\text { Space } \\
\text { group }\end{array}$ & $a, \AA$ & $c, \AA$ & $V, \AA^{3}$ & \\
\hline \multirow[t]{2}{*}{$\alpha-\mathrm{CeC}_{2}$} & $\mathrm{CaC}_{2}$ & tI6 & $I 4 / \mathrm{mmm}$ & $3.878(2)$ & $6.487(2)$ & $97.6(2)$ & $\overline{\mathrm{a}}$ \\
\hline & & & & $3.876(1)$ & $6.485(3)$ & $97.5(3)$ & $b$ \\
\hline \multirow[t]{2}{*}{$\mathrm{CeNi}_{2}$} & $\mathrm{MgCu}_{2}$ & $c F 24$ & $F d-3 m$ & $7.215(1)$ & - & $375.56(1)$ & \\
\hline & & & & $7.214(2)$ & - & $375.43(8)$ & b \\
\hline \multirow[t]{2}{*}{$\mathrm{CeNi}_{3}$} & $\mathrm{CeNi}_{3}$ & $h P 24$ & $\mathrm{P6}_{3} / m m c$ & $4.9639(3)$ & $16.520(2)$ & $352.53(9)$ & $\mathrm{a}$ \\
\hline & & & & $4.9642(4)$ & $16.522(2)$ & $352.6(1)$ & b \\
\hline \multirow[t]{2}{*}{$\mathrm{Ce}_{2} \mathrm{Ni}_{7}$} & $\mathrm{Ce}_{2} \mathrm{Ni}_{7}$ & $h P 36$ & $P 6_{3} / m m c$ & $4.9412(6)$ & $24.509(6)$ & $518.2(3)$ & a \\
\hline & & & & $4.9410(5)$ & $24.511(4)$ & $518.4(2)$ & $b$ \\
\hline \multirow[t]{2}{*}{$\mathrm{CeNi}_{5}$} & $\mathrm{CaCu}_{5}$ & $h P 6$ & P6/mmm & $4.8872(4)$ & $3.9999(3)$ & $82.74(3)$ & a \\
\hline & & & & $4.8870(2)$ & $4.0041(6)$ & $82.87(6)$ & $\mathrm{b}$ \\
\hline
\end{tabular}

${ }^{a}$ ternary sample; ${ }^{b}$ binary sample 
The three-phase regions $\left\langle\mathrm{CeNiC}_{2}+\mathrm{Ce}_{2} \mathrm{Ni}_{5} \mathrm{C}_{3}+\mathrm{C}\right\rangle$, $<\mathrm{CeNi}_{5}+\mathrm{Ce}_{2} \mathrm{Ni}_{5} \mathrm{C}_{3}+\mathrm{C}>$ and $\left\langle\mathrm{C}+\mathrm{Ce}_{2} \mathrm{Ni}_{22} \mathrm{C}_{2.75}+\right.$ $\mathrm{CeNi}_{5}>$, which were observed at $400^{\circ} \mathrm{C}$, are present also at $800^{\circ} \mathrm{C}$. The stoichiometric compositions of the binary and ternary compounds were confirmed by EDX analysis. Backscattered electron images of the alloys annealed at $800^{\circ} \mathrm{C}$ are shown in Fig. 2. Ternary compounds with the composition $\mathrm{RNiC}_{2}$

Table 2 Crystallographic data of the ternary compounds in the $\mathrm{Ce}-\mathrm{Ni}-\mathrm{C}$ system at $800^{\circ} \mathrm{C}$.

\begin{tabular}{|c|c|c|c|c|c|c|c|c|}
\hline Compound & $\begin{array}{c}\text { Structure } \\
\text { type }\end{array}$ & $\begin{array}{c}\text { Pearson } \\
\text { symbol }\end{array}$ & $\begin{array}{l}\text { Space } \\
\text { group }\end{array}$ & $a, \AA$ & $b, \AA$ & $c, \AA$ & $V, \AA^{3}$ & Ref. \\
\hline \multirow[t]{2}{*}{$\mathrm{CeNiC}_{2}$} & $\mathrm{CeNiC}_{2}$ & $o S 8$ & Amm2 & $3.8755(3)$ & $4.5490(4)$ & $6.1623(5)$ & $108.64(3)$ & $\mathrm{a}$ \\
\hline & & & & 3.875 & 4.552 & 6.162 & 108.7 & {$[4,5]$} \\
\hline \multirow[t]{2}{*}{$\mathrm{Ce}_{2} \mathrm{Ni}_{5} \mathrm{C}_{3}$} & $\mathrm{La}_{2} \mathrm{Ni}_{5} \mathrm{C}_{3}$ & $t P 20$ & $P 4 / m b m$ & $8.3033(4)$ & - & $3.9841(3)$ & $274.68(4)$ & $\mathrm{a}$ \\
\hline & & & & 8.307 & - & 3.979 & 274.6 & {$[6,7]$} \\
\hline \multirow[t]{2}{*}{$\mathrm{Ce}_{2} \mathrm{Ni}_{22} \mathrm{C}_{2.75}$} & $\mathrm{Ce}_{2} \mathrm{Ni}_{22} \mathrm{C}_{2.75}$ & $o S 216$ & Cmce & $11.374(4)$ & $15.006(3)$ & $14.622(2)$ & 2495.7(9) & $\mathrm{a}$ \\
\hline & & & & 11.373 & 15.004 & 14.625 & 2495.6 & {$[8,9]$} \\
\hline
\end{tabular}

${ }^{\mathrm{a}}$ own results
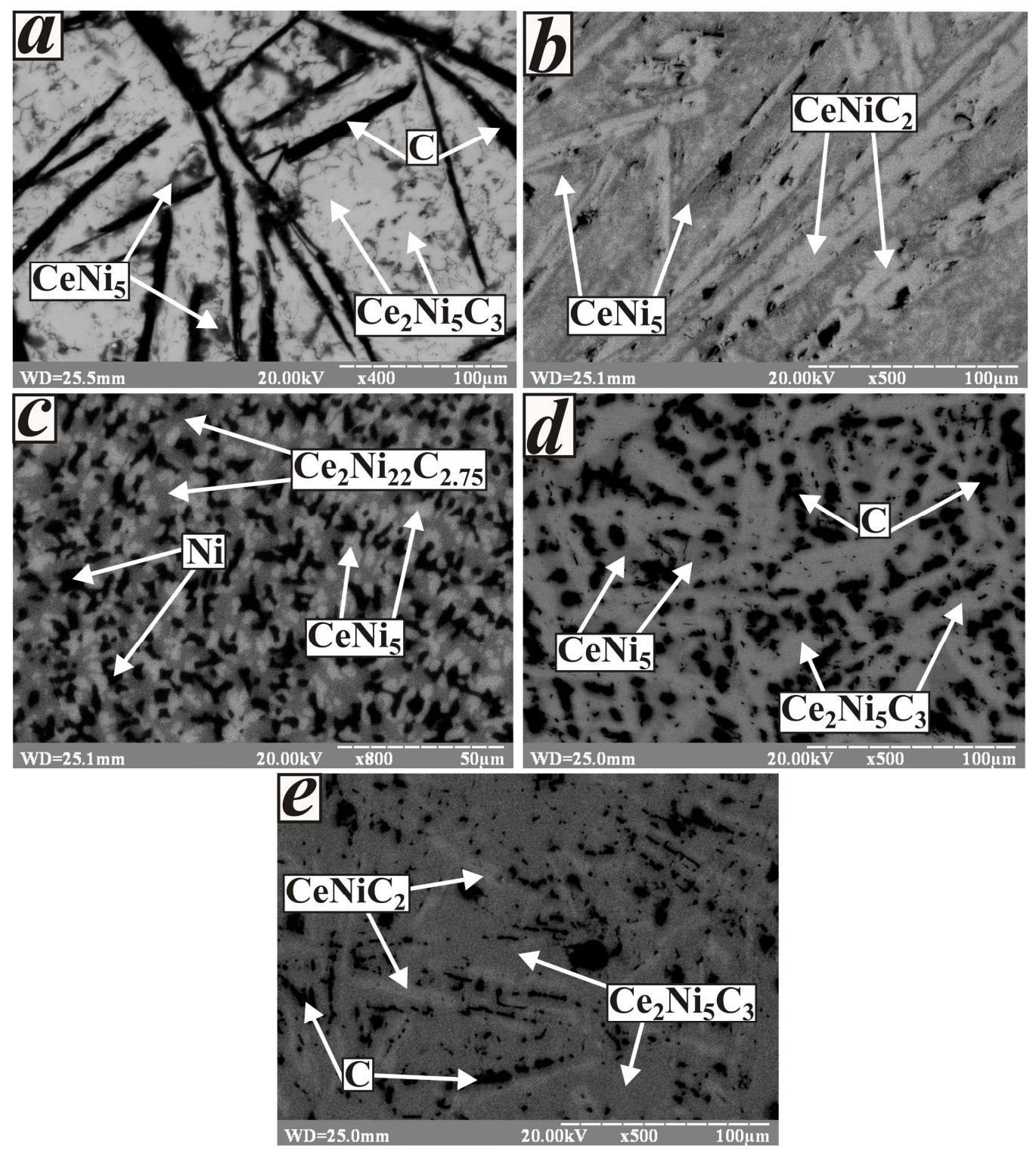

Fig. 2 Backscattered electron images of alloys annealed at $800^{\circ} \mathrm{C}: \mathrm{Ce}_{12} \mathrm{Ni}_{38} \mathrm{C}_{50}(a), \mathrm{Ce}_{21.8} \mathrm{Ni}_{47.6} \mathrm{C}_{30.6}(b$, black inclusions are surface defects), $\mathrm{Ce}_{7} \mathrm{Ni}_{87} \mathrm{C}_{6}(c), \mathrm{Ce}_{15} \mathrm{Ni}_{57} \mathrm{C}_{28}(d), \mathrm{Ce}_{19} \mathrm{Ni}_{46} \mathrm{C}_{35}(e)$. Composition of the phases is indicated according to the EDX analysis. 
$\left(\mathrm{CeNiC}_{2}\right.$-type structure) occur also in the ternary systems ( $\mathrm{La}, \mathrm{Ce}, \mathrm{Y}, \mathrm{Gd})-\mathrm{Ni}-\mathrm{C}$. In the systems (La, Ce, Gd)-Ni-C, ternary carbides $R_{2} \mathrm{Ni}_{22} \mathrm{C}_{3-x}$ with $\mathrm{Ce}_{2} \mathrm{Ni}_{22} \mathrm{C}_{3-x}$-type structures exist too. However, ternary compounds $R_{2} \mathrm{Ni}_{5} \mathrm{C}_{3}$ with $R=\mathrm{Y}$, Gd, or $R_{2} \mathrm{Ni}_{22} \mathrm{C}_{3-x}$ with $R=\mathrm{Y}$ have not been reported.

Two new ternary carbides, $\mathrm{Pr}_{2} \mathrm{Ni}_{5} \mathrm{C}_{3}$ and $\mathrm{Nd}_{2} \mathrm{Ni}_{5} \mathrm{C}_{3}$, were synthesized by arc-melting cold-pressed pellets of powdered elemental components, and their crystal structures were determined. They are new representatives of the isostructural series of $R_{2} \mathrm{Ni}_{5} \mathrm{C}_{3}$ ternary compounds with $\mathrm{La}_{2} \mathrm{Ni}_{5} \mathrm{C}_{3}$-type structures, known up to now only for $R=\mathrm{La}$ and $\mathrm{Ce}$. The new ternary carbides were observed in the as-cast and in the annealed (at $800^{\circ} \mathrm{C}$ ) alloys of nominal composition $R_{20} \mathrm{Ni}_{50} \mathrm{C}_{30}(R=\mathrm{Pr}, \mathrm{Nd})$. The crystal structures were refined by the powder XRD Rietveld method. The refined XRD profiles of the $R_{20} \mathrm{Ni}_{50} \mathrm{C}_{30}(R=\mathrm{Pr}, \mathrm{Nd})$ alloys annealed at $800^{\circ} \mathrm{C}$ are presented in Fig. 3 . Details of the refinements are summarized in Table 3 .

Table 3 Details of the full-profile refinement of XRD patterns of $\mathrm{Pr}_{20} \mathrm{Ni}_{50} \mathrm{C}_{30}$ and $\mathrm{Nd}_{20} \mathrm{Ni}_{50} \mathrm{C}_{30}$ samples annealed for 25 days.

\begin{tabular}{|c|c|c|}
\hline Phase & $\mathrm{Pr}_{2} \mathrm{Ni}_{5} \mathrm{C}_{3}$ & $\mathrm{Nd}_{2} \mathrm{Ni}_{5} \mathrm{C}_{3}$ \\
\hline Content in sample, wt. $\%$ & $84.33 \pm 1.24$ & $76.48 \pm 1.04$ \\
\hline Space group & \multicolumn{2}{|c|}{$\mathrm{P} 4 / \mathrm{mbm}$} \\
\hline$Z$ & \multicolumn{2}{|c|}{2} \\
\hline$a, \AA$ & $8.2888(1)$ & $8.2810(2)$ \\
\hline$c, \AA$ & $3.95343(8)$ & $3.9292(1)$ \\
\hline$V, \AA^{3}$ & 271.61(1) & $269.45(2)$ \\
\hline Calculated density, $\mathrm{g} \mathrm{cm}^{-3}$ & $7.4751(4)$ & $7.6173(5)$ \\
\hline Radiation; wavelength, $\AA$ & \multicolumn{2}{|c|}{ X-rays, $\mathrm{Cu} K \alpha_{1} ; 1.54056$} \\
\hline $2 \theta,{ }^{\circ} ; \sin \theta / \lambda, \AA^{-1}$ & \multicolumn{2}{|c|}{$110.64 ; 0.534$} \\
\hline$h k l$ & $0 \leq h \leq 5$ & $0 \leq h \leq 5$ \\
\hline & $0 \leq k \leq 8$ & $0 \leq k \leq 8$ \\
\hline & $0 \leq l \leq 4$ & $0 \leq l \leq 4$ \\
\hline Zero shift & -0.0001 & -0.0008 \\
\hline Preferred orientation & $1.39(2)\left[\begin{array}{lll}0 & 0 & 1\end{array}\right]$ & $1.37(2)\left[\begin{array}{lll}0 & 0 & 1\end{array}\right]$ \\
\hline$R_{\mathrm{B}}$ & 3.75 & 5.46 \\
\hline$R_{\mathrm{p}}$ & 3.28 & 2.84 \\
\hline$R_{\mathrm{wp}}$ & 4.27 & 3.69 \\
\hline$R_{\text {exp }}$ & 3.94 & 3.57 \\
\hline GooF & 1.084 & 1.034 \\
\hline Scale factor & $0.175(3)$ & $0.170(3)$ \\
\hline
\end{tabular}

Table 4 Atomic and isotropic displacement parameters for $\mathrm{Pr}_{2} \mathrm{Ni}_{5} \mathrm{C}_{3}$ and $\mathrm{Nd}_{2} \mathrm{Ni}_{5} \mathrm{C}_{3}$.

\begin{tabular}{|c|c|c|c|c|c|c|}
\hline Atom & $\begin{array}{l}\text { Wyckoff } \\
\text { position }\end{array}$ & $\begin{array}{c}\text { Site } \\
\text { occupation }\end{array}$ & $x$ & $y$ & $z$ & $B_{\text {iso }}, \AA^{2}$ \\
\hline \multicolumn{7}{|c|}{$\mathrm{Pr}_{2} \mathrm{Ni}_{5} \mathrm{C}_{3}$} \\
\hline $\mathrm{Pr}$ & $4 h$ & 1 & $0.3406(2)$ & $x+1 / 2$ & 0 & $1.24(4)$ \\
\hline Ni1 & $8 i$ & 1 & $0.2125(4)$ & $0.0775(4)$ & $1 / 2$ & $0.75(8)$ \\
\hline $\mathrm{Ni} 2$ & $2 b$ & 1 & 0 & 0 & 0 & $1.8(2)$ \\
\hline $\mathrm{C} 1$ & $4 g$ & $1^{\mathrm{a}}$ & 0 & 0 & $1 / 2$ & $1.0^{\mathrm{a}}$ \\
\hline $\mathrm{C} 2$ & $2 a$ & $1^{\mathrm{a}}$ & $0.060(2)$ & $x+1 / 2$ & $1 / 2$ & $1.0^{\mathrm{a}}$ \\
\hline \multicolumn{7}{|c|}{$\mathrm{Nd}_{2} \mathrm{Ni}_{5} \mathrm{C}_{3}$} \\
\hline $\mathrm{Nd}$ & $4 h$ & 1 & $0.3414(2)$ & $x+1 / 2$ & 0 & $1.06(5)$ \\
\hline $\mathrm{Ni1}$ & $8 i$ & 1 & $0.2120(5)$ & $0.0774(5)$ & $1 / 2$ & $0.92(1)$ \\
\hline $\mathrm{Ni} 2$ & $2 b$ & 1 & 0 & 0 & 0 & $1.6(3)$ \\
\hline $\mathrm{C} 1$ & $4 g$ & $1^{\mathrm{a}}$ & 0 & 0 & $1 / 2$ & $1.0^{\mathrm{a}}$ \\
\hline $\mathrm{C} 2$ & $2 a$ & $1^{\mathrm{a}}$ & $0.060(3)$ & $x+1 / 2$ & $1 / 2$ & $1.0^{\mathrm{a}}$ \\
\hline
\end{tabular}

\footnotetext{
${ }^{\mathrm{a}}$ constrained parameters
} 


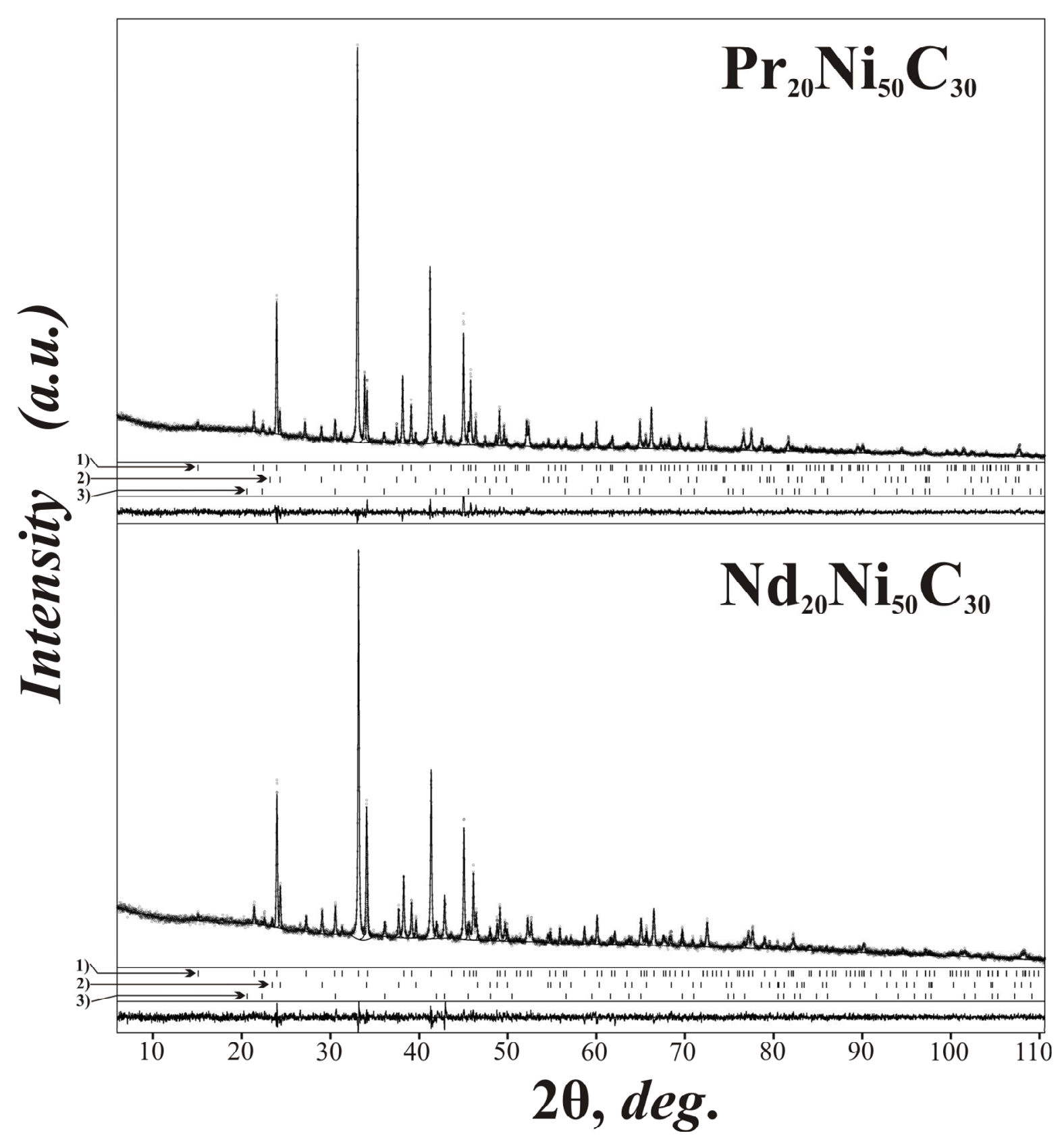

Fig. 3 Observed (dots) and calculated (line) profiles and their difference (bottom) for the XRD patterns of the $\mathrm{Pr}_{20} \mathrm{Ni}_{50} \mathrm{C}_{30}(a)$ and $\mathrm{Nd}_{20} \mathrm{Ni}_{50} \mathrm{C}_{30}(b)$ samples annealed at $800^{\circ} \mathrm{C}$ for 25 days. The Bragg positions are marked by vertical bars: 1) $\operatorname{Pr}_{2} \mathrm{Ni}_{5} \mathrm{C}_{3}(a), \mathrm{Nd}_{2} \mathrm{Ni}_{5} \mathrm{C}_{3}(b)$; 2) $\operatorname{PrNiC}_{2}(a), \mathrm{NdNiC}_{2}(b)$; 3) $\operatorname{PrNi}_{5}(a), \mathrm{NdNi}_{5}(b)$.

Atomic and isotropic displacement parameters for the structures of $\mathrm{Pr}_{2} \mathrm{Ni}_{5} \mathrm{C}_{3}$ and $\mathrm{Nd}_{2} \mathrm{Ni}_{5} \mathrm{C}_{3}$ are listed in Table 4. The unit-cell content of the crystal structure and the coordination polyhedra of the atoms in the $R_{2} \mathrm{Ni}_{5} \mathrm{C}_{3}$ compounds $(R=\mathrm{Ce}, \mathrm{Pr}, \mathrm{Nd})$ with $\mathrm{La}_{2} \mathrm{Ni}_{5} \mathrm{C}_{3^{-}}$ type structures are shown in Fig. 4. The interatomic distances calculated for the new ternary carbides are presented in Table 5. There are isolated carbon atoms (C1) and carbon pairs (C2-C2) in the crystal structure of the investigated isostructural compounds. The $\mathrm{C}-\mathrm{C}$ distances are 1.40(2) $\AA$ and 1.41(3) $\AA$ for $R=$ Pr and $\mathrm{Nd}$, respectively. For the three ternary carbides $d_{\mathrm{C}-\mathrm{C}}$ takes values intermediate between the typical distances between carbon atoms in $s p^{3}$ - and $s p^{2}$ hybridization. There are short Ni1-C interatomic distances $d_{\mathrm{Ni} 1-\mathrm{C} 1}$ and $d_{\mathrm{Ni} 1-\mathrm{C} 2}$ in the investigated compounds. The values of $d_{\mathrm{Ni1}-\mathrm{C} 1}$ and $d_{\mathrm{Ni1}-\mathrm{C} 2}$ indicate covalent bonding between the atoms. However, the $\mathrm{Ni2}-\mathrm{C} 2$ interatomic distances are almost equal to the sum of the atomic radii of the elements. 
The variation of the cell volume within the series of $R_{2} \mathrm{Ni}_{5} \mathrm{C}_{3}(R=\mathrm{La}$ [1], $\mathrm{Ce}, \mathrm{Pr}, \mathrm{Nd})$ compounds is shown in Fig. 5. The cell volumes are reduced from La to $\mathrm{Nd}$, which reflects lanthanide contraction. The cell parameters of the ternary compound $\mathrm{Ce}_{2} \mathrm{Ni}_{5} \mathrm{C}_{3}$ did not change in the investigated three-component alloys that contained this carbide. Constant stoichiometric composition was also confirmed for $\mathrm{Ce}_{2} \mathrm{Ni}_{5} \mathrm{C}_{3}$ in [8].<smiles>[CH]C(C)C</smiles>

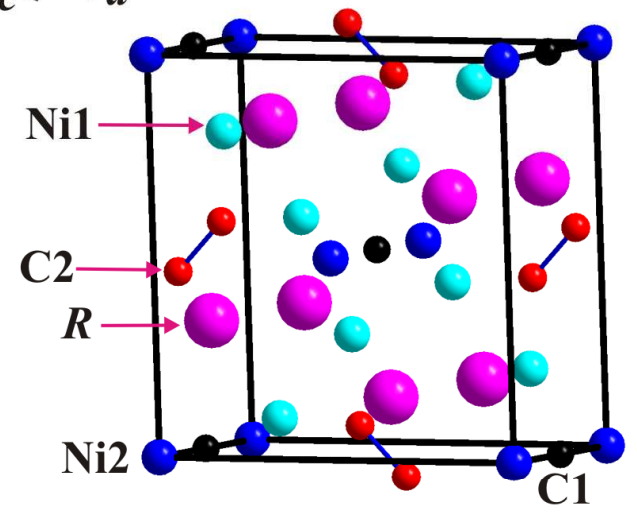

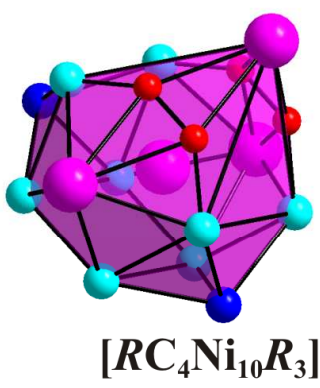
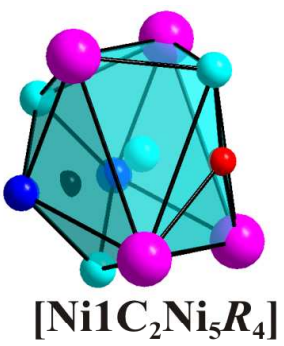
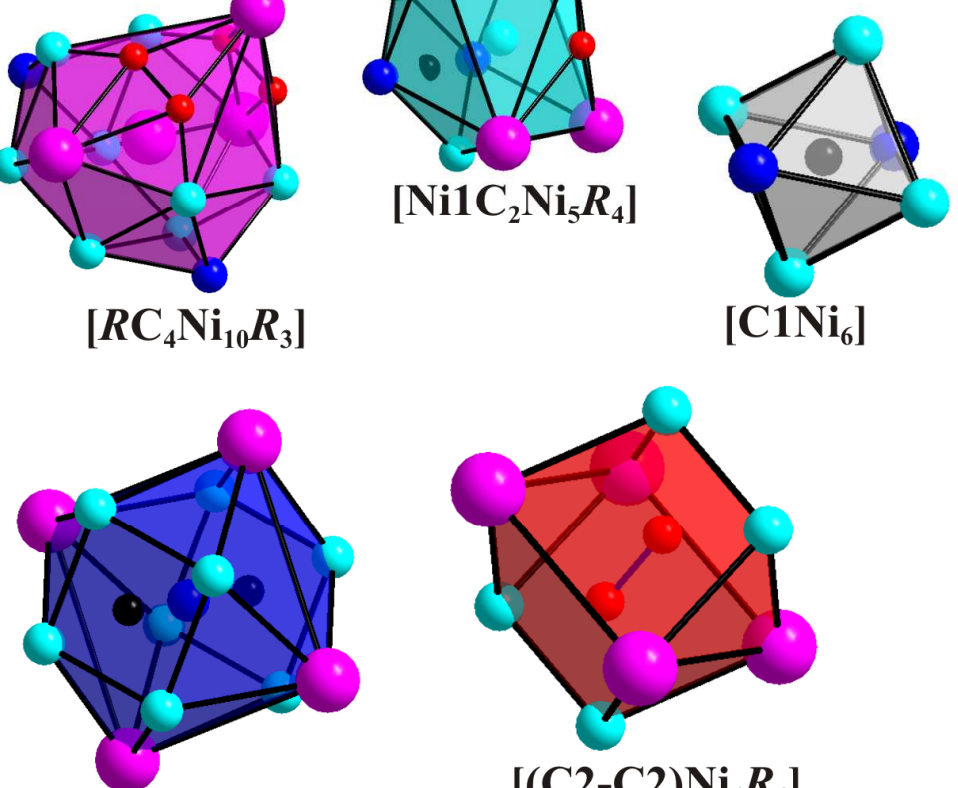

$\left[\mathrm{Ni} 2 \mathrm{C}_{2} \mathrm{Ni}_{8} R_{4}\right]$

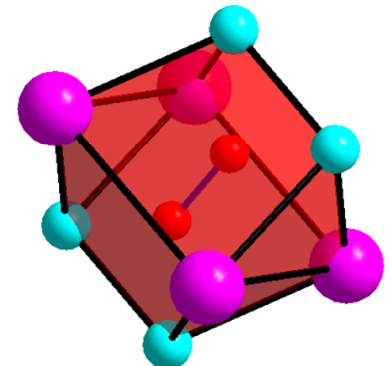

$\left[(\mathrm{C} 2-\mathrm{C} 2) \mathrm{Ni}_{4} \mathrm{R}_{4}\right]$

Fig. 4 Unit cell content and coordination polyhedra of the atoms in the crystal structure of the $R_{2} \mathrm{Ni}_{5} \mathrm{C}_{3}$ ternary compounds $(R=\mathrm{Ce}, \mathrm{Pr}, \mathrm{Nd})$ with $\mathrm{La}_{2} \mathrm{Ni}_{5} \mathrm{C}_{3}$-type structure.

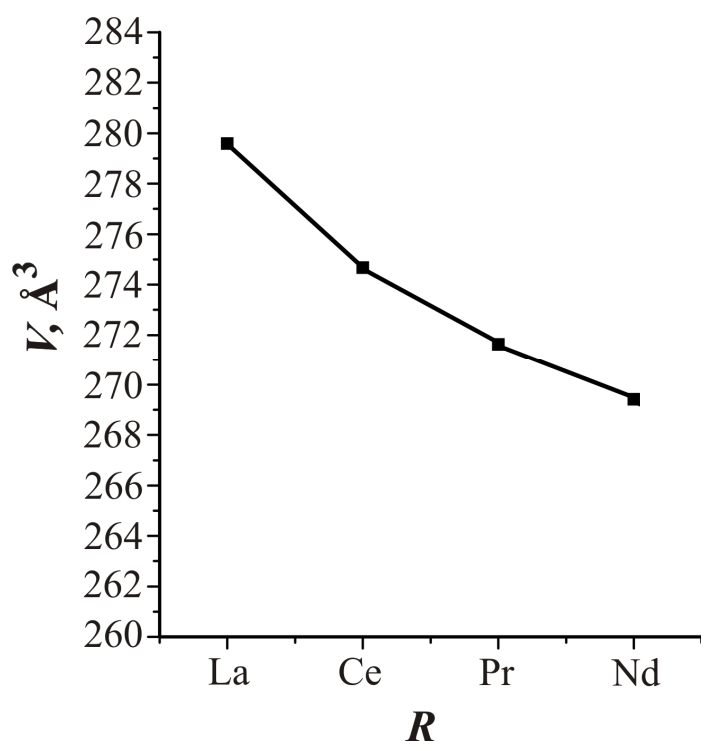

Fig. 5 Cell volumes for the series of carbides $R_{2} \mathrm{Ni}_{5} \mathrm{C}_{3}(R=\mathrm{La}[1], \mathrm{Ce}, \mathrm{Pr}, \mathrm{Nd})$. 
Table 5 Interatomic distances $(d, \AA)$ and coordination numbers $(\mathrm{CN})$ in the crystal structures of $\mathrm{Pr}_{2} \mathrm{Ni}_{5} \mathrm{C}_{3}$ and $\mathrm{Nd}_{2} \mathrm{Ni}_{5} \mathrm{C}_{3}$.

\begin{tabular}{|c|c|c|c|c|c|c|c|}
\hline \multicolumn{4}{|c|}{$\mathrm{Pr}_{2} \mathrm{Ni}_{5} \mathrm{C}_{3}$} & \multicolumn{4}{|c|}{$\mathrm{Nd}_{2} \mathrm{Ni}_{5} \mathrm{C}_{3}$} \\
\hline & toms & $d$ & $\mathrm{CN}$ & & toms & $d$ & $\mathrm{CN}$ \\
\hline $\operatorname{Pr}$ & $\begin{array}{l}-4 \mathrm{C} 2 \\
-4 \mathrm{Ni} 1 \\
-4 \mathrm{Ni} 1 \\
-2 \mathrm{Ni} 2 \\
-1 \mathrm{Pr} \\
-2 \mathrm{Pr}\end{array}$ & $\begin{array}{l}2.81(1) \\
2.976(3) \\
2.982(3) \\
3.117(1) \\
3.738(2) \\
3.954(1)\end{array}$ & 17 & $\mathrm{Nd}$ & $\begin{array}{l}-4 \mathrm{C} 2 \\
-4 \mathrm{Ni} 1 \\
-4 \mathrm{Ni} 1 \\
-2 \mathrm{Ni} 2 \\
-1 \mathrm{Nd} \\
-2 \mathrm{Nd}\end{array}$ & $\begin{array}{l}2.795(4) \\
2.971(3) \\
2.972(3) \\
3.117(2) \\
3.715(2) \\
3.929(1)\end{array}$ & 17 \\
\hline Ni1 & $\begin{array}{l}-1 \mathrm{C} 1 \\
-1 \mathrm{C} 2 \\
-1 \mathrm{Ni} 1 \\
-2 \mathrm{Ni} 1 \\
-2 \mathrm{Ni} 2 \\
-2 \mathrm{Pr} \\
-2 \mathrm{Pr}\end{array}$ & $\begin{array}{l}1.875(3) \\
1.89(2) \\
2.462(4) \\
2.651(4) \\
2.724(2) \\
2.976(3) \\
2.982(3) \\
\end{array}$ & 11 & Ni1 & $\begin{array}{l}-1 \mathrm{C} 1 \\
-1 \mathrm{C} 2 \\
-1 \mathrm{Ni} 1 \\
-2 \mathrm{Ni} 1 \\
-2 \mathrm{Ni} 2 \\
-2 \mathrm{Nd} \\
-2 \mathrm{Nd}\end{array}$ & $\begin{array}{l}1.869(4) \\
1.89(2) \\
2.466(5) \\
2.643(5) \\
2.712(3) \\
2.971(3) \\
2.972(3) \\
\end{array}$ & 11 \\
\hline $\mathrm{Ni} 2$ & $\begin{array}{l}-2 \mathrm{C} 1 \\
-8 \mathrm{Ni} 1 \\
-4 \mathrm{Pr}\end{array}$ & $\begin{array}{l}1.977(1) \\
2.724(2) \\
3.117(1) \\
\end{array}$ & 14 & $\mathrm{Ni} 2$ & $\begin{array}{l}-2 \mathrm{Cl} \\
-8 \mathrm{Ni} 1 \\
-4 \mathrm{Nd}\end{array}$ & $\begin{array}{l}1.965(1) \\
2.712(3) \\
3.117(2) \\
\end{array}$ & 14 \\
\hline $\mathrm{C} 1$ & $\begin{array}{l}-4 \mathrm{Ni} 1 \\
-2 \mathrm{Ni} 2 \\
\end{array}$ & $\begin{array}{l}1.875(3) \\
1.977(1)\end{array}$ & 6 & $\mathrm{C} 1$ & $\begin{array}{l}-4 \mathrm{Ni} 1 \\
-2 \mathrm{Ni} 2 \\
\end{array}$ & $\begin{array}{l}1.869(4) \\
1.965(1)\end{array}$ & 6 \\
\hline $\mathrm{C} 2$ & $\begin{array}{l}-\mathrm{C} 2 \\
-2 \mathrm{Ni} 1 \\
-4 \mathrm{Pr}\end{array}$ & $\begin{array}{l}1.40(2) \\
1.89(2) \\
2.81(1)\end{array}$ & 8 & $\mathrm{C} 2$ & $\begin{array}{l}-\mathrm{C} 2 \\
-2 \mathrm{Ni} 1 \\
-4 \mathrm{Nd}\end{array}$ & $\begin{array}{l}1.41(3) \\
1.89(2) \\
2.795(4)\end{array}$ & 8 \\
\hline
\end{tabular}

\section{Conclusions}

The isothermal section of the $\mathrm{Ce}-\mathrm{Ni}-\mathrm{C}$ phase diagram at $800^{\circ} \mathrm{C}$ has been investigated in the range 0-33.3 at.\% Ce. The binary compounds $\mathrm{CeNi}_{5}, \mathrm{CeNi}_{2}$, $\mathrm{CeNi}_{3}, \mathrm{Ce}_{2} \mathrm{Ni}_{7}$, and $\alpha-\mathrm{CeC}_{2}$ do not dissolve the third element. Three ternary compounds with constant compositions, $\mathrm{CeNiC}_{2}, \mathrm{Ce}_{2} \mathrm{Ni}_{22} \mathrm{C}_{2.75}$, and $\mathrm{Ce}_{2} \mathrm{Ni}_{5} \mathrm{C}_{3}$, occur in the system at $800^{\circ} \mathrm{C}$. Two new ternary carbides, $\mathrm{Pr}_{2} \mathrm{Ni}_{5} \mathrm{C}_{3}$ and $\mathrm{Nd}_{2} \mathrm{Ni}_{5} \mathrm{C}_{3}$, with $\mathrm{La}_{2} \mathrm{Ni}_{5} \mathrm{C}_{3}$-type structure have been synthesized. The compounds were observed in the as-cast alloys and after homogenization at $800^{\circ} \mathrm{C}$. They are new representatives of the isostructural series of carbides $R_{2} \mathrm{Ni}_{5} \mathrm{C}_{3}$. There are two types of carbon atoms in the crystal structure: isolated atoms and $\mathrm{C}_{2}$ pairs.

\section{Acknowledgments}

The authors are thankful to Drs V. Shtender (Karpenko Physico-Mechanical Institute, NAS of Ukraine) and P.Yu. Demchenko (Interfaculty scientific-educational laboratory of X-ray structure analysis, Ivan Franko National University of Lviv) for the XRD initial data results, and to R. Serkiz (Scientific-Technical and Educational
Center of Low-Temperature Studies, Ivan Franko National University of Lviv) for the EDX analysis.

\section{References}

[1] O.I. Bodak, E.P. Marusin, in Phase Diagrams of Refractory Systems, Metallurgiya, Kyiv, 1980, pp. 176-182.

[2] A.O. Tsokol', Visn. Lviv. Univ., Ser. Khim. 27 (1986) 41-43.

[3] H.H. Stadelmaier, S.B. Kim, Z. Metallkde. 75 (1984) 381-383.

[4] O.I. Bodak, E.P. Marusin, Dopov. Akad. Nauk Ukr. RSR, Ser. A (12) (1979) 1048-1050.

[5] K.N. Semenenko, A.A. Putyatin, I.V. Nikol'skaya, V.V. Burnasheva, Russ. J. Inorg. Chem. 28 (1983) 943-945.

[6] O.I. Bodak, E.P. Marusin, V.S. Fundamenskii, V.A. Bruskov, Sov. Phys. Crystallogr. 27 (1982) 1098-1101.

[7] A.O. Tsokol', O.I. Bodak, E.P. Marusin, Kristallografiya 31 (1986) 73-75.

[8] A. Yamada, K. Matsubayashi, Y. Uwatoko, K. Kondo, S. Katano, M. Kosaka, Solid State Commun. 150 (2010) 725-728. 
[9] R. Pöttgen, W. Jeitschko, C. Evers, M.A. Moss, J. Alloys Compd. 186 (1992) 223-232.

[10] A.A. Putyatin, K.N. Semenenko, I.V. Nikol'skaya, Zh. Obshch. Khim. 55 (1982) 529-534.

[11] A.A. Putyatin, I.V. Nikol'skaya, K.N. Semenenko, Zh. Obshch. Khim. 54 (1982) 1297-1303.
[12] W. Jeitschko, M.H. Gerss, R.D. Hoffmann, S. Lee, J. Less-Common Met. 156 (1989) 397-412.

[13] STOE Win XPOW, Version 2.10, Stoe \& Cie, 2004.

[14] L. Akselrud, Y. Grin, J. Appl. Crystallogr. 47 (2014) 803-805. 